\title{
Epistemic Options in the Face of Epistemic Barriers
}

\section{Epistemik Bariyerler Karșısında Epistemik Seçenekler}

MURAT ARICI

Necmettin Erbakan University

Received: 06.12.2014 | Accepted: 15.02.2015

Abstract: Many philosophers in analytic tradition have attempted to examine the notion of 'epistemic limits'. "Are we cognitively/epistemologically limited beings?" is a question that is answered positively in many philosophical debates. It is an uncontroversial fact that human beings face several types of epistemic barriers during their lifetime. The more significant question "What kind of epistemic position do/should we take towards epistemic barriers?" is less examined than the former. There are only a few options to take a position. Agnostic stance, which has been defended as a respectable epistemic position, is one of those. Appealing to ways other than rational and empirical methods is another. This paper, chiefly focusing on the latter question, first criticizes the agnostic stance on the grounds that it is neither compatible with human epistemic nature, nor practical in several circumstances. To justify such a claim, the paper builds several hypothetical scenarios, and through these scenarios, it reaches the conclusion that appealing to other ways of forming beliefs on what is beyond the epistemic barriers is epistemologically more tenable than taking an agnostic stance in many circumstances.

Keywords: Epistemic barrier, epistemic limit, agnosticism, knowledge, belief, belief acquisition.

\footnotetext{
This paper is an extended and revised version of the conference paper presented at The
} Asian Conference on Ethics, Religion and Philosophy, Osaka, Japan, $20 \mathrm{II}$. 


\section{Preliminaries}

Questions such as "What is knowledge?" and "How can I know what I know?" have been more commonly studied than the question "What are the limits of my knowledge?" in epistemology. Limitations of our knowledge may vary. It may result from the things external to the mind, or it may result from the capacity of our experiencing the external things, or it may result from the natural languages we use, or the structure of the conceptual system we are bound with. Examples of such include Plato's questioning of human knowledge in his Republic (1997), Kantian treatment of the thing-in-itself ${ }^{1}$ in his Critique of Pure Reason ( $\left.178 \mathrm{I}\right)$, Wittgenstein's consideration of natural languages in his Tractatus (1974). And more contemporary ones include Fodor's proposal of endogenous constraints on concepts of human beings (Fodor, I98 $3^{2}$ ), and Nagel's (I986), McGinn's (I993) and Williamson's (2000) examinations of epistemic limits.

Many take for granted that there are epistemic limits. This paper will not take that for granted. It will rather attempt to show that there exist several kinds of barriers before human epistemological practices. What bear more significance for the purpose of this paper, however, are the epistemic stances towards what is beyond our epistemic limits. Agnosticism, as one of the significant approaches, is recently claimed to be a sustainable stance towards epistemological barriers (Rosenkranz, 2007; Magnus, 2005). The paper will attempt to show, as well, that agnostic stance cannot be taken in many cases, and it is not compatible with the nature of human epistemological activities.

Here is a detailed plan for this paper: I will first categorize parts of reality, and simply propose that reality divides into three domains with respect to by which method we investigate it. My categorization will postulate the notion of "epistemic barrier" as it primary basis in order to evaluate possible approaches to what is beyond the limits of human knowledge. Accordingly, I will then ask two central questions: (I) Can empirical or rational methods be an ideal epistemic guidance for an epis-

\footnotetext{
I For an examination of Kant's treatment of thing-in-itself and Hegel's response to it, see also Kreines (2007).

2 For a critique of Fodor's view, see also Rellihan (2005).
} 
temic agent in the face of an epistemic barrier? (2) If the answer is "No," and my answer will be "No," what options are available for the agent to form beliefs on what is beyond the barrier in order to take a relevant epistemic attitude? After discussion of two possible stances as reactions to question (2), one as agnostic and the other as employing "other ways of forming beliefs," I will be defending two claims: (a) Since agnostic stance is not really compatible with human nature, the epistemic agent has no option but take the stance that appeals to other ways of forming beliefs, and (b) Adopting some other ways of forming beliefs on what is beyond the epistemic barriers-ways in which the epistemic agent applies several epistemic standards-is a credible epistemic stance.

\section{Parts of Realities}

To begin with, let us say there is the part of reality consisting of $\mathrm{em}$ pirical facts that are accessible to scientific (empirical) investigation. This part of reality comprises facts open to scientific observation and experimentation. For instance, if yo+u wish to find out what biological changes would occur if you climb to the top of an 8.000 meter-high mountain, you go climb, observe your body and do experimentation if it is necessary, and you get what you need to find out empirically. The knowledge you acquire through this way is of the states of affairs occurring in a domain that is open to any scientific investigation whose method is primarily an empirical one (including relevant rational thinking, of course). We can call this part of reality 'the domain of empirical facts.'

The domain of empirical facts does not constitute the whole reality. Another part consists of what is behind the empirical facts. You observe that you freely choose to eat an ice cream and think that what has caused the action of your eating ice cream is your free choice. But someone may intelligibly ask and utter the questions: Is your free choice the real cause of your action? Might there be some other unobservable cause that brought about both your decision of eating ice cream and your action of eating it? What is the nature of causation involved here anyway? What

\footnotetext{
3 Here, what I mean by 'fact' is any objectively observable relation between any existing observable entities. And what I mean by 'state of affairs' is simple atomic facts that does not include more than one relation between two entities. And finally, what I mean by 'reality' is the totality of truths.
} 
kind of philosophical tie takes place between cause and effect even in ordinary cases? These are metaphysical questions that are not subject to scientific observation and experimentation. There are other topics in this category like the nature of concepts, existence, knowledge, moral/aesthetic values etc. You need to do some philosophical (rational) reasoning to answer these questions. And the answers you will acquire will be primarily based on rational grounds. We may call this part of reality 'the domain of rational facts.'

The last part of reality is the main target of this paper. It is that which consists of what is beyond the empirical and rational facts. To explicate this part of reality, let us consider the notion of 'epistemic barrier,' first. To begin with an example, think about space travel. It seems that human beings cannot gain all the knowledge there is of different sections of the universe, just because they cannot travel all sections of it in an adequately short duration. This is because of its enormous size. It is so huge that even in thousands of years this may never be possible at all. This is what the world outside brings us as a limitation against our entire capacity of acquiring knowledge. There are other limitations we face on this very same subject. We may never know all there is to know of different sections of the universe, also because of our limited lifespan, brain structure, neurophysiologic features etc.

The astronauts we send for space travel may never know certain laws governing those sections of the space, just because they are biologically limited. There is more to these limitations. On the same very point, we should seriously consider our conceptual capacity as well. Our unlucky astronauts perhaps are not capable of completely conceiving certain concepts like infinity, unordinary spatiotemporal properties, backward causation in time etc. Unknown to them, this may be one of the serious obstacles they encounter in their exploration of the space. As a result, it is quite obvious that we are epistemologically limited beings, which basically means that human beings do not have the capacity of acquiring all there is to know. Let us classify the limitations in question under three groups:

(a) Universal limitations (like the enormous size of the universe and causational complexity), (b) Biological limitations (like humans' limited 
lifespan, brain structure and neurophysiology), and (c) Cognitive limitations (like our limited conceptual capacity).

Having clarified the notion of epistemic barrier, we can now think about the last part of reality, i.e., the part that consists of what is beyond the empirical and rational facts. So far I have used the term 'fact' in the sense of 'facts subject to scientific (empirical) and rational (philosophical) investigation'. Perhaps, we should now admit that there are facts closed to any scientific or philosophical investigation carried out by humans. These facts may exist unknown to us, and remain unknown forever only because we are epistemologically limited beings. Well, one might question the existence of such facts and demand a justification. But this would never be necessary. The metaphysical possibility for the existence of such facts is enough to lay out the parts of reality we are interested in. And that possibility can be shown easily by a simple metaphor. Just as an elephant is epistemologically incapable of knowing the details of quantum mechanics, it is quite plausible to assume that the world consists of facts some of which are beyond the epistemic barriers and, therefore, totally closed to human cognition epistemologically. This type of facts is what constitutes the final part of reality - the domain of what is beyond empirical and rational facts. Let us summarize these three parts of reality as follows:

(I) The domain of empirical facts: It basically consists of states of affairs open to everyday observation and/or scientific investigation.

(2) The domain of rational facts: It simply consists of states of affairs open to everyday reasoning and/or philosophical/conceptual investigation.

(3) The domain of what is beyond the empirical and rational facts (or beyond the epistemic barriers): This domain is by definition unreachable through empirical and/or rational methods. It supposedly consists of states of affairs completely closed to any scientific or philosophical investigationand obviously any everyday observation and reasoning-carried out by human beings.

\section{Epistemic Stances on the Third Domain}

Now we have reached to a point where the epistemic agent is forced to take a stance on the epistemic inadequacy that she suffers in the last domain of reality. Towards this inadequacy, there seem to be two chief 
stances to possibly take. First, she can be agnostic and believe that as long as humans are bound with those epistemic limitations mentioned above, what is beyond the epistemic barriers can never be known by humans. Second, she can hold that methods other than the empirical or rational ones can be pursued to form beliefs on what is beyond the epistemic barriers. On the former stance, the agnostic may either hold the view that forming beliefs on what can never be known, as an epistemic act, is implausible, or the view that forming beliefs on what can never be known is plausible with some certain conditions. But this latter view has to be reduced ultimately to the second stance. Before examining these two stances with details, let us give a final thought to whether or not the empirical or rational method can shed any light on this third domain-the domain that contains possible facts beyond the universal, biological and cognitive limitations surrounding human cognition.

One might think that the empirical or rational method might be helpless in the third domain, but it promises some hopes towards gaining knowledge on possible states of affairs in this third domain. Perhaps in the far future with some scientific and philosophical advances, what seems to be beyond the epistemic barriers will become knowable. In order to argue for such a view, however, one must ultimately hold that human cognition is capable of exceeding not only its own biological and cognitive limits but also the universal limitations explained above. Holding such a view would not be wise, because the axioms and principles of the empirical or rational method have already been shaped within those three kinds of limits, thus are bound with them.

Even if we give some credit to this view, it seems that the epistemic agent still has to take one of the above stances-the agnostic or the nonempirical/non-rational stance. It is because her epistemic attitude towards what is beyond the barriers has nothing to do with how the human cognitive capacity would advance in the future. The epistemic agent's predicaments result from those limitations in his lifespan, and she has to develop an attitude while she still lives. She has to take a stance while she is still epistemologically suffering from her limits. Hoping that the future generations of her own kind will be able to exceed their limits in the far future would not obviously solve her predicaments during her life. 


\section{Against Agnostic Stance on the Third Domain}

If so, it is time to examine the mentioned two possible stances towards the third domain. As to the first one, the agnostic one, I claim that it is not possible to take such a stance in those cases where the epistemic agent is either forced to take an action or under the inevitable effects of emotional and sensual states, or when curiosity wins. I would like to examine these three situations under three scenarios:

Scenario I - Being forced to take an action: Suppose that one day the researchers in NASA detect an intergalactic radio signal from a distant galaxy, which they become certain that it is not a fake one: it really comes from that galaxy. Although the signal has a complex structure, the researchers finally decode a message embedded in it. Nevertheless, after examining the message, they are not only surprised but also quite shocked. For, the message exactly says "we will destroy the Earth.” Well, this is just a thought experiment, but like most of the thought experiments, it is aimed to reveal our intuitions that we are not aware of in normal conditions. Now, it is clear that the researchers in NASA face several epistemic barriers one of which is the distance between the Earth and the galaxy from which they received the signal. Nonetheless, they have to form some beliefs on the origins of the message, the likely sender, the available data regarding that distant galaxy and so on. They have to do this because relevant authorities have to take an action; otherwise life on Earth might end. It seems that the researchers cannot be agnostic on such a scenario: They cannot say, for example, "it is implausible to form beliefs on something we do not have enough data to do so."

Scenario 2 - Facing Death: Think about Betty who is a full-fledged agnostic. For her, there is nothing to believe on what is beyond the epistemic barriers such as death. Suppose that Betty undergoes, very sadly, a lethal disease. She knows that she is going to die soon because of this deadly illness. Since her disease is not a mental one, nothing prevents her from rational thinking. So, she can perfectly undergo such processes of rational thinking that humans are mortal, that she is human, and that sooner or later she was going to die, so nothing to worry about and no revision is necessary in her belief system. Is this how Betty apt to think? The answer is clearly "no." She will most probably begin to consider seri- 
ously her agnostic epistemic attitude towards what is beyond death even though she had already been aware of the reality of death before. What cause her to consider a revision of her epistemic attitude are the emotional and sensual states she experiences. It is obvious that her emotions and desires will heavily influence what beliefs she is going to form on what is beyond the barrier of death. One thing is very clear: Her agnostic epistemic attitude will not get strengthened; rather it will get gradually weakened. The reason for this is that her previous agnostic stance was not fully natural; rather it was the result of a suppression that suppressed the awareness of a very natural cause: death. This means that she was not fully aware of the reality of death before, and, as a result, her agnostic stance has not been well established epistemologically. If this is a true description of Betty's epistemological situation, we should be clear about one question: Which is epistemologically more credible, Betty's previous full-fledged agnostic stance or the likely revised epistemic position of her facing death? A friend of agnosticism against epistemic barriers might be more inclined to methodological naturalism and claim that whatever hypothetically exists beyond death should not affect our epistemic activities. But this would undermine her agnostic position, since in justifying her agnostic stance, the full reality of a very natural cause, death, cannot be neglected. Note that what is important here is not whether Betty will revise her epistemic stance or not. Rather, the significant point here is that the possibility that she would revise her epistemic stance is seen to be more plausible by our epistemic intuitions.

Scenario 3 - Incomprebensibility: As I mentioned earlier, it is possible that there exist things that are incomprehensible to human cognition. Infinity, some awkward spatiotemporal properties like simultaneity in relativity theory, backward causation in time etc. can be re-mentioned here. In fact there is no need to mention such examples; just the metaphysical possibility that somewhere in the universe there is an entity with a highly complex incomprehensible organization is enough to construct such an argument. So, suppose that there are entities whose organizations are incomprehensible by human. Obviously, this would not mean that such an organization cannot be comprehended by any beings even in principle. Somewhere in the universe, there can be a being which is capa- 
ble of comprehending this organization. So, it is not plausible to take such a stance on this incomprehensibility that no being can acquire the knowledge of it. Rather, it is quite reasonable to form beliefs on it, beliefs that are not produced by empirical or rational method, but acquired in some other ways.

\section{Other Ways of Forming Beliefs}

Although other scenarios can be constructed, I believe the ones given above constitute good reasons to be convinced that for what is beyond the epistemic barriers, agnosticism is not an actual option compatible with the real nature of human beings. The next step then is to examine the other stance that other ways of forming beliefs about what is beyond the epistemic barriers should be welcomed epistemologically. Other means of forming beliefs should be welcomed, because it is the human epistemological nature that forces epistemic agents to form beliefs, in some or other ways, on the third domain. This is what happens in belief forming processes of epistemic agents. A normativist in epistemology, at this point, may express his concern that epistemic agents are bound with epistemic duties, and these duties restrain him to form such beliefs on those grounds that have not been approved by pre-established epistemic norms. Such a concern can be resolved by the fact that no method of forming beliefs on the third domain would and could be built groundlessly. The epistemic practices we the human beings perform are all guided by an inner truth-seeking epistemic behavior. No epistemic agent can believe something false while she is aware of its falsity. Hence, it is obvious that other ways of forming beliefs on the third domain will have some epistemic grounds. The problem is of the epistemic quality of such grounds.

At this point, a question concerning the epistemic legitimacy of those other ways arises: How are the beliefs formed by ways other than the empirical or rational ones going to be evaluated in order to see if the beliefs acquired by the epistemic agent rely on epistemologically good grounds? In other words, what standards are those beliefs on what is beyond the epistemic barriers supposed to meet?

To answer the above question, we need to think about if we are talk- 
ing about determining a set of epistemic standards, or detecting the set of epistemic standards already having been applied by the epistemic agents? It depends on one's epistemic stance indeed. If one is a normativist in epistemology, one must be talking about the former; but if one is a naturalist in epistemology, one must be talking about the latter. Here, the reader should be reminded of the chief concern of this paper. The primary goal of this paper has been to show that epistemic agents who appeal to other ways of forming beliefs on what is beyond the epistemic barriers cannot be judged carelessly that she presents implausible epistemic behaviors. Given this goal, the matter of determining a set of epistemic standards for the relevant purpose is beyond the scope of this paper. What this paper aims to argue only requires showing that epistemic agents who appeal to the ways of forming beliefs other than the empirical or rational ones, in fact, employ certain epistemic standards either deliberately or unintentionally. This and the previous conclusion I reachedthat the empirical/rational methods or the agnostic stance are not options for an epistemic agent in forming beliefs on the third domain-will suffice for the final conclusion that beliefs gained by other ways cannot be judged ruthlessly that they are epistemologically groundless.

It seems that epistemic agents who appeal to other ways of forming beliefs employ two kinds of standards: internal and external. Internal standards are those which are imposed internally by the dynamics of the method adopted. External standards, on the other hand, are those by which the epistemic agent judges the beliefs externally to make sure that his beliefs are somehow connected to the other two domains-empirical and rational domains. To exemplify the usage of these standards, take John who has believed for years in an eternal life after death. He accordingly believes that he will continue to live even after he dies. Clearly, he, or anyone else, cannot find an empirical support for such a belief. Nor can he construct a well-established rational basis for that belief. Nevertheless, he employs several epistemic standards in holding the belief of that sort.

Authenticity of the belief, how supported from the sources the belief is, the reliability of those sources and so on can be good examples of the internal standards. John, on the other hand, demands that his belief about 
life after death is not completely isolated from what he knows about the empirical and rational domains-i.e., his belief is epistemologically connected to the world he lives in. That is why he also applies several external epistemic standards to his belief - standards that are independent of the internal dynamics of the belief system he submitted himself to. The external standards John employs may come from a number of sources such as his previous empirical experiences (empirical compatibility), rational principles (like consistency), and his emotional and sensual states (convenience to his emotions and desires). All these deliberate or undeliberate applications clearly show that John does not choose what he beliefs randomly in an epistemic sense, which makes his believing act of that sort epistemologically respectable.

\section{Conclusion}

What I have claimed so far can be summarized as follows: There are epistemic barriers that we the human beings face in our epistemic practices. Ordinary orthodox methods like empirical and rational ones do not help in knowing what is beyond the barriers. On the other hand, using other methods to form beliefs on what is beyond the barriers is not groundless. It is rather epistemologically a credible one. Here is the chief reasoning I have used to support this view: The domains of reality divides into three parts: The domain of empirical facts, the domain of rational facts, and the domain of beyond empirical and rational facts. The facts existing in the last domain cannot be known by empirical or rational methods by definition. Seemingly, an epistemic agent has two options towards this kind of facts unreachable by empirical or rational methods. She can either adopt an agnostic stance or she can appeal to other ways of forming beliefs about the states of affairs in this domain.

Through several argumentative scenarios, I have argued that for an epistemic agent, agnostic stance is not a real option compatible with human nature. Hence, her appealing to other ways of forming beliefs on the third domain is a sort of epistemological necessity. This necessity together with the epistemic standards she applies to her beliefs acquired by non-empirical/non-rational ways provides, I claim, a kind of epistemic legitimacy for her beliefs of this sort. Whether or not these beliefs are 
true regarding the third domain is something beyond the scope of this paper, and does not affect the conclusion that forming beliefs through ways other than the empirical or rational methods on what is beyond the epistemic barriers can perfectly be sustainable epistemological reactions to the barriers in question.

\section{References}

Fodor, J. (1983). The Modularity of Mind: An Essay on Faculty Psychology. Cambridge, Massachusets: MIT Press.

Kant I. (1998). Critique of Pure Reason (trans. P. Guyer \& A. W. Wood). Cambridge: Cambridge University Press.

Kreines, J. (2007). Between the Bounds of Experience and Divine Intuition: Kant's Epistemic Limits and Hegel's Ambitions. Inquiry, 50 (3), 306-334.

Magnus, P. (2005). Peirce: Underdetermination, Agnosticism, and Related Mistakes. Inquiry, 48 (I), 26-37.

McGinn, C. (1993). Problems in Philosophy: The Limits of Inquiry. Oxford: Blackwell Publishing.

Nagel, T. (1986). The View from Nowhere. Oxford: Oxford University Press.

Plato (1997). Republic (trans. G. M. A. Grube). Complete Works (ed. J. M. Cooper). Indianapolis: Hackett Publishing.

Rellihan, M. (2005). Epistemic Boundedness and the Universality of Thought. Philosophical Studies, 125 (2), 219-250.

Rosenkranz, S. (2007). Agnosticism as a Third Stance. Mind, 46I, 55-IO4.

Williamson, T. (2000). Knowledge and its Limits. Oxford: Oxford University Press.

Wittgenstein, L. (1974). Tractatus Logico-Philosophicus (trans. D. F. Pears \& B. F. McGuinness). London \& New York: Routledge. 
Öz: Analitik felsefe geleneğinin pek çok düșünürü 'epistemik sınır' nosyonu üzerine kafa yormuștur. "Kognitif ya da epistemolojik açıdan sınırlı varlıklar mıyız?" sorusu farklı felsefi tartıșma bağlamlarında olumlu bir șekilde yanıtlanmaktadır. İnsanoğlunun yașam süreci boyunca değișik türlerde epistemik bariyerlerle yüz yüze geldiği neredeyse tartıșmasız bir olgudur. Bunun yanında "Farklı epistemik bariyerler karșısında ne tür epistemik durușlar sergiliyoruz/sergilemeliyiz" sorusu ilk soruyla kiyaslandığında daha az incelemeye tabi tutulmuștur. Doğrusu bu ikinci soruya cevap anlamında takınabilecek belli başlı birkaç epistemik tavır olabilir. Epistemolojik açıdan meșru bir pozisyon olarak savunulmuş ve savunulmakta olan agnostik tavır bunlardan bir tanesidir. Rasyonel ve ampirik yöntemin dıșında bir takım yollara bașvurmak bașka bir alternatiftir. Bu ikinci tavrı merkeze alan bu makale, ilk olarak agnostik tavrı eleștirmekte, bu tavrın hem insan doğasının epistemik yönüyle örtüșmediğini hem de belli türden sorunsal durumlarda pratik olanla uyumlu olmadığını iddia etmektedir. Makale, bu iddiayı temellendirmek için olası bir takım senaryolar inșa etmekte ve bu senaryolar aracılığı ile șu sonuca ulașmaktadır: Epistemik bariyerlerle yüzleșilen pek çok durumda, epistemik bir bariyerin ardına dair rasyonel ve ampirik olanın dıșında bir takım yollara başvurarak epistemik inanç geliștirmek, epistemolojik olarak, agnostik tavır takınmaktan daha savunulabilir pozisyondur.

Anahtar Kelimeler: Epistemik bariyer, epistemik limit, agnostisizm, bilgi, inanç, inanç edinimi. 